\title{
70-kDa heat shock cognate protein expression as a putative biomarker of heavy-metal burden in Mytilus galloprovincialis

\author{
Ivana Ratkaj ${ }^{1}$, Paula Žurga², Aleksandar Bulog², Jasna Peter-Katalinić ${ }^{2}$ and Sandra Kraljević Pavelić ${ }^{*}$
}

\begin{abstract}
Background: Heavy metals naturally occur in the marine environment and ecosystems. Due to anthropogenic influence they became common waters and coastal regions pollutants in particular where their concentrations remain hazardously high. We therefore tested a protocol for combined analysis of 6 heavy metal $(\mathrm{Pb}, \mathrm{Cd}, \mathrm{Cr}, \mathrm{Zn}, \mathrm{Fe}$ and $\mathrm{Hg}$ ) concentrations in mussels Mytilus galloprovincialis collected from a coastal industrial zone (shipyard locality) and mariculture facilities in combination with expression analysis of multi xenobiotic resistance related genes and stress-related gene (HSC-70).
\end{abstract}

Findings: In this paper we tested a protocol for heavy-metal levels assessment by use of a highly sensitive analytical method, ICP-OES, combined with expression analysis of multi xenobiotic resistance related genes, including the stress-related gene encoding 70-kDa heat shock cognate protein on mussels (Mytillus Galloprovincialis). Mussels from the shipyard locality had higher heavy metal concentrations, except Fe. Higher metal concentrations did not influence expression of multi xenobiotic resistance related genes with exception of stress-related gene (HSC-70) encoding 70-kDa heat shock cognate protein.

Conclusions: Our results indicate that mussels sampled in the industrial area have increased metal concentrations in comparison with the aquaculture locality, that are accompanied by increased transcript levels of HSC-70.

Keywords: Heavy metals; Mytilus galloprovincialis; HSC-70

\section{Introduction}

Heavy metals naturally occur in the marine environment and ecosystems. Due to excessive anthropogenic influence, they have been growingly recognized as important factors underlying pathogenesis of several diseases. Indeed, they are amongst most common pollutants of waters in general (Spada et al. 2013). They are non-degradable and occur in forms or concentrations that have harmful effects on living organisms (Maanan 2007). In particular, increased concentrations of heavy metals, highly hazardous for marine ecosystems are being reported in coastal regions that are increasingly exploited for fishing and mariculture in (Spada et al. 2013). Therefore, there is a growing concern about health risk related to increasing heavy metals presence in the marine environment and consequently in marine

\footnotetext{
* Correspondence: sandrakp@biotech.uniri.hr

'Department of Biotechnology, University of Rijeka, Radmile Matejčić 2,

51000 Rijeka, Croatia

Full list of author information is available at the end of the article
}

organisms for food consumption (Annicchiarico et al. 2010). It is expected that development of -omics methods applied to environmental research will provide improved and more sensitive protocols or models for assessment of environmental issues, i.e. identification of environmental biomarkers related to health (García-Sevillano et al. 2013). A recently recognized model system for heavy metal contamination assessment is the marine mussel-based system due to mussels' ability to accumulate heavy metals and thus, reflect the environmental pollution (Fang et al. 2003). Previous studies have shown that expression of multi xenobiotic resistance (MXR)-related genes and those that code for heat-shock proteins (HSP) family genes, might be used as indicators of environmental stress caused by contaminants (Franzellitti and Fabbri 2005; Luedeking and Koehler 2004). Herein, we present a proof-of concept protocol for combined assessment of heavy metal pollution and environmental stress in the coastal region or coastal mariculture 
facilities by use of the mussel Mytilus galloprovincialis system as a general bioindicator of environmental pollution.

\section{Material and methods}

\section{Samples and biometry}

Mussels Mytilus galloprovincialis were collected in the spring period of 2013 at two locations in Croatia, including the facility for mussel production in Limski kanal - Istria (a total of 15 mussels) and the industrial zone, with increased heavy-metal pollution, of the Third May Shipyard -Rijeka (a total of 15 mussels). Mussels were immediately transported into laboratory in plastic containers filled with $1 \mathrm{~L}$ of sea water per 1 mussel. Biometric analyses were conducted according to Crosby and Gale (Crosby and Gale 1990). Briefly, mussel's height, width and length were measured and, after dissection, soft tissue was removed, weighted and dried at $60{ }^{\circ} \mathrm{C}$ for $48 \mathrm{~h}$. Condition index (CI) was calculated from weight of dried tissue and internal capacity of a shell according to the formula $\mathrm{IC}=$ mass of dried tissue $(\mathrm{g}) \times 1000 /$ capacity of a shell (g). Final biometry data is presented as a mean value \pm standard deviations.

\section{Analysis of heavy metals}

The dried soft tissues were pooled according to the location of mussel's origin and two pooled samples were made: industrial pollutant region sample and cultivating location sample. Those samples were further dried at $60{ }^{\circ} \mathrm{C}$ to constant weight and homogenised to a powder. For microwave digestion of samples, needed for the analysis of lead, cadmium, chromium, iron and zinc, three aliquots of approx. $0,5 \mathrm{~g}$ were weighed from each sample. For mercury analysis, where no digestion was needed, three aliquots of approx. $0,2 \mathrm{~g}$ were weighed from each sample. All results were expressed on a dry matter basis and presented as mean values \pm standard deviations.

The samples were digested in the Anton Paar Multiwave 3000 microwave system (Perkin Elmer, USA) equipped with pressurized vessels, using $5 \mathrm{~mL}$ of $65 \%$ nitric acid per sample $\left(\mathrm{HNO}_{3}\right.$ Suprapur, Merck, Germany), over a $20 \mathrm{mi}-$ nutes operation cycle at $200{ }^{\circ} \mathrm{C}$. The digested samples were then transferred to $25 \mathrm{~mL}$ volumetric flasks and ultrapure water (Siemens) was added to the mark.

The concentrations of six metals were determined. Lead $(\mathrm{Pb})$, cadmium $(\mathrm{Cd})$, chromium $(\mathrm{Cr})$, zinc $(\mathrm{Zn})$ and iron (Fe) were determined using the ICP-OES Optima 8000 equipped with S10 autosampler (Perkin Elmer, USA). The determination of total mercury $(\mathrm{Hg})$ was performed using the mercury analyzer AMA254 (Leco, USA). Analytical blanks were prepared and run in the same way as the samples. The concentrations of metals were determined using external standards, with standard solutions prepared in the same acid matrix. Standards for the instrument calibration were prepared on the basis of multielement certified reference solution for ICP (Perkin Elmer, USA) and single element certified reference solution for mercury (LGC Standards, USA). The method for ICP-OES was validated using the IAEA-407 reference material (fish tissue), (International Atomic Energy Agency, Austria). Mean recoveries for $\mathrm{Pb}, \mathrm{Cd}, \mathrm{Cr}, \mathrm{Zn}$ and $\mathrm{Fe}$ were 93,1 \%, 103 \%, 90,1 \%, $94,3 \%$ and $91,4 \%$, respectively. The method for total mercury was validated using the Standard Reference Material (mussel tissue), NIST 2976. Mean recovery for total mercury was $104,4 \%$. The detection limits for the methods were $(\mu \mathrm{g} / \mathrm{L}): \mathrm{Pb} 3 ; \mathrm{Cd} 0,5 ; \mathrm{Cr} 0,9 ; \mathrm{Fe} 1,5 ; \mathrm{Zn} 9 ; \mathrm{Hg}$ 0,08. Certified Reference Material and procedures were used to evaluate trueness and repeatability of the analyses.

\section{Gene expression analysis}

Total RNA was isolated from the foot of 30 mussel by RNeasy spin columns (Qiagen) according to manufacturer's recommendations and 20 ng of RNA was reversely transcribed into cDNA by High Capacity cDNA Reverse Trancsription Kit (Applied Biosystems, Life technologies, USA) on GenAmp PCR System 2400 (Applied Biosystems, Life technologies). Expression of $s 18$ (housekeeping gene), $M d r, M v p$, Pgp and HCP-70 genes was determined with

Table 1 Detailed list of primer pairs and labelled probes used in the GPCR reaction

\begin{tabular}{|c|c|c|c|}
\hline Gene & Sequence $5^{\prime}-3^{\prime}$ & FAM labelled probe & Conditions \\
\hline \multirow[t]{2}{*}{$\mathrm{s} 18^{\mathrm{a}}$} & For GGTACGTGATATGCCTAC & CCTGCTGCCTTCCTTGGATG & $53^{\circ} \mathrm{C}$ \\
\hline & $\operatorname{Rev}$ CCAGGAGTGGGTAATTTG & & \\
\hline \multirow[t]{2}{*}{ Mvp } & For GAAGGAGACTATTGACAGA & TCTTCTTCACCAGCCATTCCTCA & $53^{\circ} \mathrm{C}$ \\
\hline & $\operatorname{Rev}$ CCACAACTTCTTCATAAGC & & \\
\hline \multirow[t]{2}{*}{ Pgp } & For AACGCACATGACTTCATA & CTCTGGCAATGGCTACTCGTT & $53^{\circ} \mathrm{C}$ \\
\hline & $\operatorname{Rev}$ CAGGATTCTTGGGTCTCTA & & \\
\hline \multirow[t]{2}{*}{ Mdr } & For GCCTITGTGATTGGTTTA & ATCTCCTCCTTCAGAACAATGGTGAT & $53^{\circ} \mathrm{C}$ \\
\hline & Rev GACAGATTAATTGTCGTTGA & & \\
\hline \multirow[t]{2}{*}{ HSC-70 } & For GACTCTCTGTTTGAAGGA & TACAAGCATCACAAGAGCCAGGT & $53^{\circ} \mathrm{C}$ \\
\hline & $\operatorname{Rev}$ CATGGTTCCTCTGAAAAG & & \\
\hline
\end{tabular}


Table 2 Biometric parameters of analysed mussels with condition index

\begin{tabular}{|c|c|}
\hline Location & Condition index $(\mathrm{Cl})$ \\
\hline \multirow[t]{8}{*}{ Industrial pollutant region } & $17,82 \pm 8,52$ \\
\hline & length $(\mathrm{cm}): 6,04 \pm 0,48$ \\
\hline & width $(\mathrm{cm}): 3,48 \pm 0,37$ \\
\hline & height $(\mathrm{cm}): 2,11 \pm 0,22$ \\
\hline & mass (g): $27,72 \pm 7,24$ \\
\hline & shell mass (g): 11,64 $\pm 3,00$ \\
\hline & dried tissue (g): 2,13 $\pm 1,45$ \\
\hline & wet tissue (g): 7,89 $\pm 4,23$ \\
\hline \multirow[t]{8}{*}{ Cultivating location } & $23,07 \pm 8,24$ \\
\hline & length $(\mathrm{cm}): 6,40 \pm 0,23$ \\
\hline & width $(\mathrm{cm}): 3,37 \pm 0,21$ \\
\hline & height $(\mathrm{cm}): 2,16 \pm 0,13$ \\
\hline & mass (g): $27,48 \pm 2,21$ \\
\hline & shell mass (g): 9,60 $\pm 0,99$ \\
\hline & dried tissue (g): 2,25 $\pm 1,00$ \\
\hline & wet tissue (g): 4,92 $\pm 3,68$ \\
\hline
\end{tabular}

primers and fluorescent FAM labeled probes (SigmaAldrich, Sigma Life Science) listed in Table 1 on iCycleriQ real time PCR Detection System (Bio-Rad, USA). All individual samples were analysed in triplicate and analysis of gene expression in mussels from polluted shipyard locality was compared with gene expression in mussels from the production facility (control samples) by use of standard software Rest 2009 V2.0.13. Obtained results for each group were combined and results are presented as average fold change. Statistically significant changes for fold change $>2$ (at $\mathrm{p}<0.05)$ was calculated.

\section{Results and discussions}

Heavy metal contamination has been recognized as one of the most persistent problem in ecosystems that ultimately influences human health due to bioaccumulation of metals in the food chain (Nandi et al. 2012). The main goal of this paper was therefore, to test a combined protocol on mussels (Mytillus Galloprovincialis) as bioindicators of heavy metal accumulation and accompanying stress for assessment of heavymetal pollution in a polluted shipyard locality. For that purpose we used a combined protocol for analysis of stress-related gene (HSC-70), multi xenobiotic resistance (MXR)-related genes' status and six heavy metal concentrations in mussels from a chosen location with predicted heavy-metal pollution (shipyard location) in comparison with cultivated mussels grown in an ecologically stable unpolluted environment for mariculture. Biometric analysis revealed that mussels from both locations exhibited similar condition parameters including length, width and height (Table 2). Biometric similarity points to relatively uniform general environmental conditions at both localities. Importantly, higher metal concentrations were measured in mussels collected in the industrial zone. These were four times higher for lead and zinc, three times higher levels for chromium and two times higher for mercury in comparison with levels measured in cultivated mussels (Table 3). Iron concentration was higher in cultivated mussels probably due to greater local availability in the ecosystem which is non-toxic per se (George and Coombs 1977; Szefer et al. 2004). High lead concentrations are probably due to exposure to industrial discharges or city waste-water systems in the shipyard locality. Moreover, zinc overload in mussels might be also a result of larger available zinc quantities released from sediments disturbed by boat traffic. Having in mind that increased metal concentrations were assessed in the shipyard locality, we expected to measure higher expression levels of MXRrelated genes involved in the detoxification system as well (Châtel et al. 2012; Kurelec 1997). However, no significant changes in expression of MXR-related genes in mussels with higher metal levels were observed (Fig. 1). On the other hand, the stress-related gene encoding $70-\mathrm{kDa}$ heat shock cognate $(H S C-70)$ protein transcript proved to be statistically increased in mussels from the shipyard locality. Previous research (Franzellitti and Fabbri 2006) has similarly provided evidence for increased HSC-70 transcript expression after $8 \mathrm{~h}$-exposure of mussels to $\mathrm{CH}_{3} \mathrm{Hg}^{2+}$ while exposure to $\mathrm{Hg}^{2+}$ alone induced increased HSC-70 expression only after 6 day-treatment. Similar induction of the HSC-70 gene was observed in mussels exposed to $\mathrm{Hg}^{2+}$ and $\mathrm{Cr}^{6+}$ (Franzellitti and Fabbri 2005). This might explain increased transcript levels of HSC-70 in mussels with higher total metal concentrations in the presented study as well. HSP7O is the most abundantly expressed proteins among the HSP family and has a constitutive expression in unstressed conditions (Hartl and Hayer-Hartl 2002). Changes in the

Table 3 Concentration of six heavy metals (lead (Pb), cadmium (Cd), total mercury ( $\mathrm{Hg})$, chromium ( $\mathrm{Cr})$, zinc ( $\mathrm{Zn})$ an iron (Fe)) in mussel samples taken from the shipyard locality and cultivating location (results are expressed on a dry matter basis)

\begin{tabular}{|c|c|c|c|c|c|c|}
\hline Location & $\mathrm{Pb}(\mathrm{mg} / \mathrm{kg})$ & $\mathrm{Cd}(\mathrm{mg} / \mathrm{kg})$ & Total Hg (mg/kg) & $\mathrm{Cr}(\mathrm{mg} / \mathrm{kg})$ & Zn (mg/kg) & $\mathrm{Fe}(\mathrm{mg} / \mathrm{kg})$ \\
\hline Industrial pollutant region & $4,043 \pm 0,222$ & $1,278 \pm 0,055$ & $0,159 \pm 0,005$ & $2,827 \pm 0,152$ & $404,5 \pm 15,6$ & $116,8 \pm 10,1$ \\
\hline Cultivating location & $0,995 \pm 0,033$ & $0,855 \pm 0,031$ & $0,079 \pm 0,004$ & $0,99 \pm 0,026$ & $117,5 \pm 6,7$ & $256,4 \pm 18,4$ \\
\hline
\end{tabular}




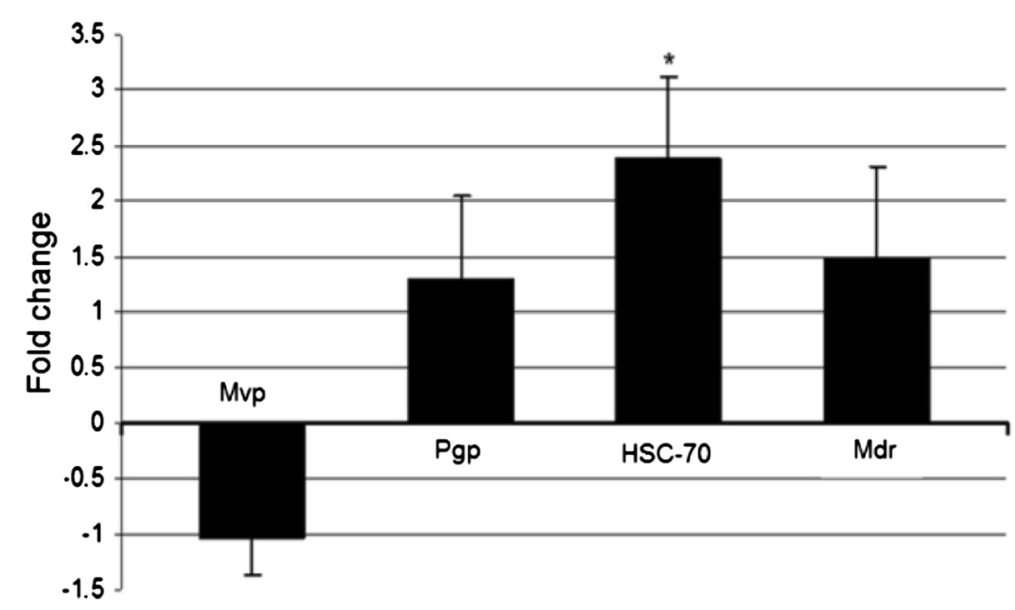

Figure 1 Average expression of stress-related gene encoding 70-kDa heat shock protein (HSC-70) and multi xenobiotic resistance-related transporters Mvp (major vault protein), Pgp (permeability glycoprotein) and Mdr (multidrug-resistance gene) in mussels collected from polluted region in comparison with mussels from the cultivating location. Statistically significant change (fold change $>2, p<0.05$ ) is marked with an asterisk (*).

mussel environment might often cause its over-expression (Franzellitti and Fabbri 2005; Piano et al. 2005). HSC-70 is however, less stress-dependent in comparison with other stress-related genes and its role might be rather specialized, i.e. in long-term cytoprotection against inorganic metal contamination (Franzellitti and Fabbri 2006; Ali et al. 1996). We believe that observed alterations in HSC70 gene expression in mussels from the shipyard locality with higher metals level provide additional evidence on the sensitivity of Mytillus galloprovincialis to environmental changes, such as for example metal pollution as metal levels in analysed mussel specimens pointed only to moderately polluted waters. Moreover, we have shown that tested combined protocol for analysis of heavy-metal levels and activation of $H S C-70$ gene in edible mussels (Mytillus galloprovincialis) might be used for efficient biomonitoring, especially in mariculture facilities. Still, presented study has some limitations that prevent us from more conclusive observations. In particular, a smaller number of specimens were analysed and only two localities were chosen for comparison of evaluated parameters. The same study design should therefore, be repeated on a larger number of specimens collected from various locations and at different seasons to achieve more reliable data and comprehensive conclusions.

\section{Abbreviations \\ MXR: Multi xenobiotic resistance; HSP: Heat shock protein; Cl: Condition index; ICP-OES: Inductively coupled plasma optical emission spectrometry; HSC-70: 70-kDa heat shock cognate protein; Mvp: Major vault protein; PgP: Permeability glycoprotein; Mdr: Multidrug-resistance gene.}

\section{Competing interests}

The authors declare that they have no competing interests.

\section{Authors' contributions}

IR has been involved in samples collection, performing and analysing gene expression, drafting the manuscript, $\mathrm{PZ}$ and $\mathrm{AB}$ have been involved in sample collection and heavy metal analysis and drafting the manuscript, JPK and SKP analysed and reviewed the results, participated in drafting the manuscript and gave final approval. All authors read and approved the final version of the manuscript.

\section{Acknowledgements}

Presented work was supported by the Croatian Science Foundation project "High throughput analytical platforms for Adriatic-brand food quality and authenticity" and University of Rijeka research grant 511-21. We greatly acknowledge the help of Dr. Elitza Markova-Car in the primer design.

\section{Author details}

'Department of Biotechnology, University of Rijeka, Radmile Matejčić 2, 51000 Rijeka, Croatia. ${ }^{2}$ Teaching Institute for Public Health of Primorsko-goranska County, Krešimirova 52a, 51000 Rijeka, Croatia.

Received: 10 February 2015 Accepted: 29 April 2015

Published online: 14 July 2015

\section{References}

Ali A, Salter-Cid L, Flajnik MF, Heikkila JJ (1996) Isolation and characterization of a cDNA encoding a Xenopus 70-kDa heat shock cognate protein, Hsc70.I. Comp Biochem Physiol 113:681-687

Annicchiarico C, Assennato G, Blonda B, Cardellicchio N, Di Leo A, Giandomenico S, Lopez L, Spada L, Umgaro N (2010) Preliminary results of pollutants biomonitoring in coastal marine and transitional waters od Apulia Region (Southern Italy). Fresenius Environ Bull 19:1841-1847

Châtel A, Faucet-Marquis V, Perret M, Gourlay-Francé C, Uher E, Pfohl-Leszkowicz A, Vincent-Hubert F (2012) Genotoxicity assessment and detoxification induction in Dreissena polymorpha exposed to benzo[a]pyrene. Mutagenesis 27(6):703-711

Crosby MP, Gale LD (1990) A review and evaluation of bivalve condition index methodologies with a suggested standard method. J Shellfish Res 91:233-237

Fang ZQ, Cheung RY, Wong MH (2003) Heavy metals in oysters, mussels and clams collected from coastal sites along the Pearl River Delta, South China. J Environ Sci (China) 15:9-24

Franzellitti S, Fabbri E (2005) Differential HSP70 gene expression in the Mediterranean mussel exposed to various stressors. Biochem Biophys Res Commun 336:1157-1163

Franzellitti S, Fabbri E (2006) Cytoprotective responses in the Mediterranean mussel exposed to $\mathrm{Hg} 2+$ and $\mathrm{CH} 3 \mathrm{Hg}+$. Biochem Biophys Res Commun 351:719-725

García-Sevillano MA, García-Barrera T, Gómez-Ariza JL (2013) Inorganic mass spectrometry-based metallomics for environmental monitoring of terrestrial ecosystems affected by metal pollution using Musspretus as bioindicator. J Integr OMICS 3:88-91 
George SG, Coombs TL (1977) Effects of high stability iron-complexes on the kinetics of iron accumulation and excretion in Mytilusedvlis (L.). J Exp Mar Biol Ecol 28:133-140

Hartl FU, Hayer-Hartl M (2002) Molecular chaperones in the cytosol: from nascent chain to folded protein. Science 295:1852-1858

Kurelec B (1997) A new type of hazardous chemical: the chemosensitizers of multixenobiotic resistance. Environ Health Perspect 105:855-860

Luedeking A, Koehler A (2004) Regulation of expression of multixenobiotic resistance (MXR) genes by environmental factors in the blue mussel Mytilus edulis. Aquat Toxicol 69:1-10

Maanan M (2007) Biomonitoring of heavy metals using Mytilus galloprovincialis in Safi coastal waters, Morocco. Environ Toxicol 22:525-531

Nandi S, Srivastava RC, Agarwal KM (2012) Lead and cadmium accumulation in fresh water fishes Labeo rohita and Catla catla. J Environ Res Dev 6:748-752

Piano A, Franzellitti S, Tinti F, Fabbri E (2005) Sequencing and expression pattern of inducible heat shock gene products in the European flat oyster, Ostrea edulis. Gene 361:119-126

Spada L, Annicchiarico C, Cardellicchio N, Giandomenico S, Di Leo A (2013) Heavy metals monitoring in the mussel Mytilus galloprovincialis from the Apulian coast (Southern Italy). Mediterr Mar Sci 14:99-108

Szefer P, Kim BS, Kim CK, Kim EH, Lee CB (2004) Distribution and coassociations of trace elements in soft tissue and byssus of Mytilus galloprovincialis relative to the surrounding seawater and suspended matter of the southern part of the Korean Peninsula. Environ Pollut 129:209-228

\section{Submit your manuscript to a SpringerOpen ${ }^{\circ}$} journal and benefit from:

- Convenient online submission

- Rigorous peer review

- Immediate publication on acceptance

- Open access: articles freely available online

- High visibility within the field

- Retaining the copyright to your article

Submit your next manuscript at $>$ springeropen.com 